\title{
POPULATION POLICIES IN THE SINO-SOVIET BLOC
}

\section{W. Parker Mauldin*}

During the long history of mankind, population changes have occurred largely without benefit or hindrance of specific population policies. Migration policies have sometimes been adopted in order to increase the population or labor force within a given area; more often, such policies have been restrictive. Reductions in mortality have always been sought, and with tremendous success during the twentieth century, particularly during the past decade and a half. But it is only within the past several decades that governments have begun to consider and sometimes adopt population policies designed to change birth rates. In northern and western Europe, such policies stem from a desire to increase the low birth rates. In agricultural countries, such as India and Pakistan, population policies have been adopted that are designed to lower the birth rate, and thus to decrease the rate of increase of population.

The vast majority of countries do not have well-formulated population policies. Nonetheless, the relationships between population, on the one hand, and economic or political factors, on the other hand, are significant, although not easily quantifiable. The statistical correlation between size and power probably is not very high, but it is worth noting that all really large nations are of considerable consequence in world affairs. Each of the four nations having a population of more than 100,000,000 is a political power-Mainland China, India, the Soviet Union, and the United States. It may be that bigness and power politics are inseparable. This point of view has been expressed as follows: ${ }^{1}$

Very few people in India understand the handicaps of Bigness. They do not recognise that, while Bigness in terms of the Indian Union can only be used in a Pickwickian sense with reference to the highly industrial countries of the West, it is still an image in the minds of smaller nations such as Ceylon and Nepal, which consider that bigness in itself is an element in power. We in India have dissociated ourselves with the idea of the exercise of power in areas near to us. But, curiously irrationally, we argue that bigness is inseparable from power in the West. Thus, we are hoist with our own petard. For, while we deny our association with politics in spite of our bigness, we are very loth to assume that other big or rich nations can permit themselves similar acts of self-abnegation.

Much of the world is institutionalized in praise of growth. Premier Khrushchev dramatized this point of view in saying: ${ }^{2}$

* B.S. 1935, Clemson College; M.S. 1936, University of Virginia. Associate Demógraphic Director, The Population Council, Inc. Formerly Chief, Foreign Manpower Research Office, United States Burcau of the Census. Contributor to periodicals.

${ }^{1}$ India and Nepal: Equal Partnership, 34 Eastern Economist 321 (1960).

'Radio Moscow Broadcast to Southeast Asia, July 4, 1958, as translated in Birth Control Propaganda, East Europe, July I959, p. 32. 
If about roo million people were added to our 200 million, even that would not be enough. Under Socialism the rising of the birth rate is regarded not only as a means of providing greater labor power. The Socialist State also looks at the matter from the viewpoint of the nation's future.

The Mainland Chinese also have spoken with pride about their huge population of more than $600,000,000$, and about their large annual rate of and absolute increase, amounting to $13,000,000-15,000,000$. Sulzberger, writing in the New York Times, states that "the greatest Chinese weapon in the power struggle is a massive population."3

Such points of view are not universal. For a brief period in Mainland China, approximately 1956 to 1958 , there was concern about the size and rapidity of growth of population, and birth control was introduced and advocated. India, the world's second most populous country, with more than $400,000,000$ people, views its currently high rate of population growth-about two per cent, or more than $8,000,000$ annually ${ }^{4}$ -as a detriment to economic development. Pakistan, with a population of $90,000,000$, shares India's concern. Northern and western Europe have relatively high population densities, in large part the result of appreciable rates of population growth over an extended period during the industrial revolution. There, modest rates of population growth are viewed as desirable; high ones are not.

What is meant by population policy? A strict interpretation of the term would . include only legislation that is designed to affect the size, structure, and distribution or characteristics of the population. ${ }^{5}$ A more liberal definition of population policy would include all legislation having any effect upon the demographic composition and size of a country's population. Broadly speaking, there are three types of measures that may be included under population policy: first, measures affecting the economics and health of the family, including not only marriage loans and family allowances, but also various types of maternity grants and maternity and infantwelfare services; second, provisions that impinge directly upon the control of fertility -that affect access to contraceptives and to birth-control advice, and that determine the grounds for legal abortion; and third, the wide range of policy relating to immigration and emigration. ${ }^{6}$

As Glass states, developments under these heads, in general, do not represent conscious attempts to influence population growth: ${ }^{7}$

${ }^{3}$ Sulzberger, Communist China's Novel Imperial Plan?, N.Y. Times, June 27, I96o, p. 24, col. 4 .

'R: K. Som \& A. K. De, Current Population Estimates for India, a paper presented at the Indian Sociological Conference, Lucknow, India, 1960; Indian Statistical Institute, Preliminary Estimates op Birta and Death Rates and of the Rate of Growth of Population table 3.I (National Sample Survey No. 36 , I959).

'See Hope Eldridge, Population Policies: A Survey of Recent Developments 5 (I954).

- See Glass, Foreword to ELDRIDGE, op. cit. supra note 5, at iii.

${ }^{7}$ Id. at iv. 
In two countries only are there coherent and comprehensive policies-in France, where family welfare measures are influenced by a desire to encourage at least a slow growth in numbers; and in Sweden, where social welfare aims are also combined with a desire to arrest falling fertility, but where voluntary parenthood is an explicit basis of policy. In some other countries there are particular measures designed to influence the size of the population. Immigration provisions in Australia, for example, reflect a desire for more rapid population growth, whereas the relaxation of abortion and birth control laws in Japan since World War II were conscious reactions against the pro-natalist policies of the pre-war years.

Little attention will be devoted here to those policies greatly affecting population change but which are adopted for reasons largely unrelated to changing the size, composition, distribution, or rate of growth of population. For example, public health measures have brought about major declines in mortality, particularly in the past fifteen years. This reduced mortality is the direct cause of the tremendous spurt in the rate of population growth. But the reasons for the initiation or acceptance of public health measures have nothing, or virtually nothing, to do with attempting to change the rate of growth of population. The allocation of major funds to health protection has not been influenced by a desire for more people, nor by a desire for a more rapid increase in population. The desire for a healthy, happy, long, and useful life is universal, and this provides the impetus for seeking and insisting upon good medical care.

Another example of public action greatly affecting population growth is that of urbanization and industrialization. In the western world and in the Soviet Union, the process of urbanization and industrialization has been accompanied-or closely followed-by major declines in birth rates. As a result, current rates of natural increase-excess of births over deaths-in northern and western Europe are quite modest, about 0.6 per cent annually, while in countries having primarily an agricultural economy, the comparative figure today is more often two to three per centor three to five times as rapid a rate. ${ }^{8}$ On the other hand, it is doubtful whether the high rate of natural increase in agricultural economies could have been realized without the importation from industrial societies of knowledge, techniques, equipment, and supplies that have been brought to bear on the reduction of morbidity and mortality-all of which has taken place without any appreciable change in the birth rates in the agricultural countries.

Reductions in birth rates, as an over-all policy, were not sought by nations until after World War II. Declines in the birth rate have occurred as a by-product of action taken by the state and the business community to meet other goals. Some of the goals have been to increase personal income, to increase nonagricultural production, to strengthen the national economy, etc. In no instance, however, has action been taken to increase urbanization and industrialization because of a desire to change birth rates. As a matter of fact, for the most part, changes in birth rates have been

${ }^{8}$ U.N. Dep't of Economic and Social Affairs, Demographic Yearbook tables 9, 25 (U.N. Pub. Sales No. 1959.XIII.I). 
brought about by the individual decisions of thousands and thousands-millions and millions - of couples, often in the face of opposition of the major institutionalized. forces: the church, the government, the newspapers, the press, the legal system, and the educational structure. ${ }^{9} \quad$ Accordingly; the experience of nations or other large groups in bringing about a reduction in birth rates is of quite recent origin, and is. quite limited.

If the above statements seem perhaps to be somewhat too categorical, it should be understood that they have been made without qualification both in order to. emphasize the major point, and also because the exceptions are thought to be trivial.

Considering the demographic dimensions of world politics, to borrow a phrase from Philip Hauser, ${ }^{10}$ one may divide the world into three groups of nations. The traditional grouping is the free nations, the communist countries, and the uncommitted countries. One may also divide the nations of the world into the industrialized West, the communist bloc, and the agricultural countries. This paper is primarily concerned with population policy in the communist-bloc countries.

\section{SOVIET UNION}

The traditional communist view toward population growth has been antiMalthusian. The communist population doctrine originated with the writings of Marx, who severely criticized Malthus for his population theory. ${ }^{11}$ Overpopulation, Marx reasoned, was inherent in, and characteristic of, the capitalist mode of production, which required a surplus laboring population for its expansion. Hence, overpopulation was a relative concept; it existed because, of necessity, there had to. be more workers than jobs under capitalism. Primitive and barbaric societies, living communal or extended family lives, could not experience overpopulation, which is also impossible in a socialist society, where the elimination of labor for profit ensures. the productive utilization of the entire labor force, according to Marx. That resources might be in short supply is brushed aside in communist doctrine by a supreme faith that "the productivity of the land can be infinitely increased by the application of capital, labour and science."12

Adherence to this pronatalist view is understandable in the light of the Soviet. Union's recent demographic history. Since the communists gained power in the Soviet Union a little more than forty years ago, it has sustained losses of some $75,000,000-80,000,000$ people. The first nine years produced a deficit, according to Lorimer, ${ }^{13}$ of $25,000,000-30,000,000$ people, so frightful were the war and the postwar

${ }^{-}$See Myrdal, Indian Economic Planning, 3 Population Rev. 17, 30 (1959).

${ }^{10}$ Philip M. Hauser, Demographic Dimensions of World Politics, Vice Presidential Address, Section K, American Association for the Advancement of Science, Chicago, Ill., Dec. 27, 1959.

${ }^{21}$ See Ronald L. Meek (Ed.), Marx and Exgels on Marthus (L. \& R. L. Meek transl. 1953).

${ }^{12} \mathrm{~F}$. Engees, Outlines of a Critique of Political Econosiy (1844), as quoted in Meek, op. cit. supra note II, at 57,58 .

${ }^{13}$ Frank Lorimer, The Population of the Soviet Union: History and Prospects ch. 3 (League of Nations Pub. No. 1946.II.A.3). 
conditions between 1917 and 1926. An additional loss of approximately 5,000,000 lives ${ }^{14}$ ensued during the period of the collectivization of agriculture, the settlement of the nomads, and the initial phase of the drive toward development of resources and rapid industrialization. Losses during World War II are estimated at about $45,000,000$ people, including actual deaths plus the deficit in births. ${ }^{15}$

In consequence of these losses, the rate of natural increase in the Soviet Union has been very modest during the history of that nation-about 0.8 per cent annually..$^{10}$ It would, indeed, be surprising if the Soviets did not feel the need for more people, at least in some age groups. For example, the small cohorts born during the early war years are now entering the labor force. "Net additions to the working-age population currently run around one million persons annually or only about half the number two or three years earlier."17

There are a number of parallels between the United States and the Soviet Union, in so far as the demographic situation is concerned. Each is a huge land, rich in resources, with a relatively low population density. In the United States, large-scale migration was encouraged up until the beginning of World War I. There has been implicit in the thinking of our business and government leaders the idea that population growth is inherently a good thing. This is due, in large measure, to the fact that over the long course of history, our country has prospered, while at the same time, our population has increased from 3,900,000 in 1790 to about $180,000,000$ today. The Soviet Union also has a large territory rich in resources and a relatively small-although large in absolute terms-population. When one considers this in light of its meager rate of population growth during the last forty years, it is easy to understand that most, if not all, of the Soviet planners would, indeed, prefer a larger, more rapidly increasing population. The current growth rate in the Soviet Union is about $I .8$ per cent annually, roughly the same as the average for the world as a whole. ${ }^{18}$

Some of the legislation in the Soviet Union relating directly to population seems inconsistent when examined from the above point of view. Specific legislation has sometimes been pronatalist, sometimes antinatalist, in effect. Those policies adopted within the framework of attempting to affect population growth, however, have been pronatalist in intent.

\section{A. Migration}

Legislation with reference to migration is one-sided. On the one hand, it regards flight abroad or refusal to return from abroad as punishable by death and the con-

${ }^{14} I d$. at 133 .

${ }^{15}$ Eason, The Soviet Population Today, 37 Foreign Afrairs 598, 599-600 (1959), estimates that there were $25,000,000$ more deaths than expected and 20,000,000 fewer births.

20 Computed on the basis of a I9I4 population of $140,400,000$ and a 1959 population of $208,800,000$. See Lormer, op. cit. supra note 13, at 36; N.Y. Times, Feb. 4, 1960, p. 5, col. 2.

${ }^{17}$ Kantner, The Population of the Soviet Union, in STAFF of Subcommite on Economic Statistics of the Jont Economic Committee, 86th Cong., ist Sess., Comparisons of the United States and Soviet ECoNomies pt. I, at 31 (Comm. Print 1959).

${ }^{28}$ U.N. Dep't of Economic and Social Affairs, Demographic Yearbook tables 9, 25 (U.N. Pub. Sales No. I959.XIII.I). 
fiscation of property, or by imprisonment from ten to fifteen years and the confiscation of property. ${ }^{19}$ From 1934 to December 25 , 1958, escape or flight abroad was considered as high treason, punishable by death or, if there were mitigating circumstances, by imprisonment for a term of ten years, and by confiscation of property in either case. ${ }^{20}$ This highly restrictive legislation is consistent with a desire for a larger population, although there is no evidence that this played a part in the enactment of the legislation.

Curiously enough, Soviet law is silent on the rights of citizenship or conditions under which persons may take up permanent residence in the Soviet Union. There have been periods when former citizens were encouraged to return to the homeland. But each case of immigration is a matter for administrative disposition without benefit of statutory guidance. Certainly, the Soviet Union has not encouraged largescale migrations from other countries. The meager quotas of the United States lead to far more migration into the United States than the restrictive policies of the Soviet Union do to migration into the Soviet Union.

The data on external migrations are few and confusing. In a broad sense, however, they are unimportant. There have been no substantial outmovements of peoples from the Soviet Union, with the exception of Poles and Germans caught in territory occupied by the Soviets early in World War II. Approximately $1,500,000$ Poles and Jews living in the former Polish territory were repatriated to Poland, and an additional half million came back to Poland during the years $1945-48$ from the Soviet Union, where they had moved during the war. ${ }^{21}$ There was a similar movement of Germans from East Prussia and from former German territory now controlled by Poland. But aside from these special movements of people, there has been only an occasional migrant from the Soviet Union. Emigration simply is not permitted.

B. Fertility 22

Abortion laws and family-allowance schemes may be thought of as being directly related to fertility changes. Abortion laws have been enacted primarily to prevent clandestine operations rather than to influence the course of the birth rate. ${ }^{23}$ Family-allowance schemes, however, have been introduced in many countries as a device for increasing the birth rate, or for preventing a further decline in the birth rate.

\section{Abortions}

Soviet abortion laws have gone through four distinct phases. In the I9I7-20

10 Decree of the Presidium of the U.S.S.R. Supreme Soviet, Dec. 25, 1958, Pravda, Dec. 26, I958.

${ }^{20}$ Decree of the U.S.S.R. Central Executive Committee, June 8, 1934, Izvestiya, June 9, 1934.

21 International Labour Office, Internationar Migration 1945-1957, at 63 (New Series No. 54, 1959).

13 This section draws heavily on the writes's paper, Fertility Control in Communist Countries: Policy and Practice, in Milbank Memorial Fund, Population Trends in Eastern Europe, the USSR and Mainzand China i79 (I960).

${ }^{23}$ Except in Japan, where permissive abortion laws were enacted in order to reduce the birth rate. 
period, the Czarist law was presumably still in effect, under which abortion was illegal, even on medical indications. The first Soviet decree came on November 18, x920, legalizing abortion by a surgeon, in recognition of the harm caused by its .clandestine practice, and advocating contraception. ${ }^{24}$ The era of legality came to an end in 1936 with the passage of an antiabortion law by the Council of People's Commissars of the Soviet Union, prohibiting abortion except when continued pregnancy threatened life or health..$^{25}$ Since 1955 , abortion has been legal in the Soviet Union, ${ }^{26}$ again in recognition of the health hazards to women who undergo abortion outside legitimate medical channels.

These abortion decrees were the outcome of critical social, economic, and demographic developments. That the first measure was one establishing the legality of abortion was eminently consistent with communist doctrine on the status of women. Lenin had emphasized repeatedly that "the main task is to draw the women into socially productive labor, extricate them from 'domestic slavery'."27 Equality with men meant both the right and responsibility of a woman to pursue a career and enter the labor force. "Public dining rooms ... kindergartens-are examples which can emancipate women and abolish their inferiority to men." ${ }^{28}$ "In the earlier years personal adornment of a woman was 'bourgeois', men interfered with her work, babies took away her 'freedom'."29

But a drastic decrease in the birth rate occurred in the Soviet Union between 1926 and 1936. The birth rate dropped from the low forties (per 1,000 population) in 1926 to about thirty in 1934 and $1935^{30}$ This represents the sharpest decline in the birth rate of any country in the world, except that of Japan after World War II. In part, this decline in the birth rate is traceable to the extraordinary changes in the economic and social organization of the Soviet Union during these years. Rapid industrialization and urbanization led to the dislocation of large numbers of people. The forced collectivization of farms during periods of low crop yields led to tremendous hardships, including millions of deaths. Under these extremely difficult conditions, the number of abortions increased greatly. The number of births was sharply reduced from over 6,500,000 in 1926 and 1927 to less than 5,000,000 in 1935 . The reduction in fertility was also associated with an increase in the frequency of divorce. $^{31}$ By 1934 , the number of abortions was as large as the number of births in many areas of the Soviet Union; it was extensive in the cities of Central Asia,

\footnotetext{
26 Ministerstvo zDravokhraneniya, Postanotleniya KPSS 1 sovetskogo pravitel'stVa ob okinanye

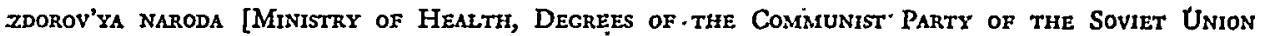
and of the Soviet Government on the Protection of the Health of the Population] 63 (1958).

${ }^{25} I d$. at $265-66$.

se" Id. at 333 .

27 V. I. LENIN, WOMEN ANd SOCIETY 27 (1938).

${ }^{28}$ Id. at I4.

29 Rose MAURer, SOVIet WOMEN 38 (I944).

${ }^{30}$ LoRIMER, op. cit. supra note I3, ch. 9 .

. ${ }^{\text {sx Ibid. }}$
} 
R.S.F.S.R., and the Ukraine. In Moscow, the number of abortions was 2.7 times the number of births in $1934^{32}$

In an effort to counteract the trend toward abortion and reduced natality, educational and social measures were advanced in 1934.

Measures for the protection of mothers and children were strengthened. Regulations issued in 1935 forbade abortions in the case of first pregnancy, and prescribed only curettage without anesthetic within three months after pregnancy, with a minimum of at least six months between operations. Much attention was given in Soviet medical literature to the technique of "painless birth." 33

It is interesting to note that births in Moscow increased from 57,000 in 1934 to 70,000 in 1935 . The number of abortions reported was approximately 155,000 in both years. ${ }^{34}$

Public attention was directed toward a campaign aimed at prohibiting abortions, which with great fanfare was decreed in 1936 as the "Law on Abortions and Aid to Mothers." N. V. Krylenko, People's Commissar of Justice of the R.S.F.S.R., hailed the law as "a whole system of measures directed toward a single aim, the aim of protecting the health of more than half of the population of the USSR, that is to say, the women. . .."35 The law prohibited abortions except when continuation of pregnancy threatened a woman's life or undermined her health, as noted above, or in cases where there was a danger of transmitting a serious disease to the child. In Moscow, the number of abortions in the third quarter of 1936 amounted to only seven per cent of the number performed within the same period a year earlier. ${ }^{36}$ In the whole Soviet Union, therapeutic abortions decreased from the first half of 1936 to the second half of 1937 by ninety-seven per cent, ${ }^{37}$ and secret abortions reportedly dropped considerably too. ${ }^{38}$

This legislation restricting abortions remained in effect for almost twenty years, until 1955, when a decree entitled "The Repeal of the Prohibition of Abortions" was issued by the Presidium of the Supreme Soviet. The text accompanying the decree carries the statement, "the repeal of the prohibition on abortions will permit the limitation of the harm caused to the health of women by abortions carried on outside of hospitals."

Information on the extent of the abortion problem in the Soviet Union is limited. The number of uncertified cases of abortions is reported to have decreased sharply after repeal of the abortion law, but "still remains significant." ${ }^{39}$ The repeal of the I 936 law has had no apparent effect on the birth rate. The need to intensify meas-

${ }^{32} I d$. at $127-30$.

${ }^{33} \mathrm{Id}$. at $\mathrm{I} 28$.

34 Id. at 127 .

${ }^{36}$ N. V. Krylenko, Love, Fanily Life, Career (n.d.).

${ }^{36}$ LoRMmer, op. cit. supra note $\mathrm{I}_{3}$, at $\mathrm{I} 27$.

${ }^{37}$ Granat, Report from the First Session of the Commission on Obstetrics, July 4-5, 1938, Akusherstvo i ginekologiya, No. 2-3, r939.

${ }^{38}$ Shening-Parshina, Medical-Explanatory Work on the Problem of Abortion, Fel'dsher $i$ akusherka, No. 2, 1957, p. 49.

${ }^{30}$ Id. at 50 . 
ures for preventing abortions still figures in the $1956-65$ plan for the development of public health, which also provides for an increase in the number of hospital beds for abortions of 0.4 per 1,000 of population by $1965 .{ }^{40}$ This represents an absolute increase of more than 80,000 hospital beds for anticipated abortions. In certain cities (Sverdlovsk, Vitebsk, Saratov), the problem must be acute, to judge by the waiting time for the operation. ${ }^{41}$ Recent reports from a Moscow hospital state that since November 1955 , the institution has performed fifteen to twenty operations a week, ${ }^{42}$ or about twenty per cent of the number of births. The United States Public Health Mission to the Soviet Union, having recently visited a number of hospitals, reports a range in the number of abortions of thirty to eighty-five per cent of all births in those hospitals. ${ }^{43}$ In one of the Frunze hospitals (Kirgizia) in 1956, there were 1,425 abortions performed or treated to 2,367 births delivered at or assisted by the hospitals, or sixty per cent. ${ }^{44}$ A Soviet Medical Mission to India reported the number of abortions to be in excess of one million in $1957,{ }^{45}$ suggesting that abortions constitute about twenty per cent of the total number of births.

\section{Family allowances}

The 1936 Soviet decree, mentioned earlier, also included provision for annual allowances for large families, extension of maternity leave, an increase in maternity homes, nursery beds, kindergarten facilities, etc. ${ }^{48}$ Undoubtedly these provisions were introduced partly for humanitarian reasons, partly to increase the availability of women to the labor force. They may also have been intended to increase the number of births. As a matter of fact, the reported birth rate rose from about thirty in 1935 to thirty-eight in 1938 ; it fell to thirty-one in $1940^{47}$

The pronatalist program was greatly intensified during World War II, when provision was made for the award of motherhood medals and a liberal system of financial allowances was introduced. The awards provided in the 1936 decree were liberalized in 1944, when a decree was issued granting an allowance for the third and higher births, as well as annual allowances for the fourth and following children. This program has continued, except that the amount of payment was reduced by one-half beginning in 1947. At the birth of the third child and of each

${ }^{10}$ Golubev, Prospective Plan for the Development of the U.S.S.R. Public Health, Meditsinskii rabotnik, Nov. 26, r957, p. 3 .

${ }^{4}$ See Nikonchik, In the Interest of Protecting Women's Health, id., March 10, 1959, p. 2.

${ }^{2}$ H. \& E. Alt, Russin's ChILdRen 146 (1959).

ts See W. Sullivan, Soviet Surgery Advances Found by Visiting American Scientists, N.Y. Times, July 21, 1959, p. I, col. 2 ; p. 8 , col. 3 .

"U.S. Public Health Service, Dep't of Health, Education and Welfare, The Report op the United States Public Health Mission to Union of Soviet Socialist Republics 30 (1959).

${ }^{45}$ See Margaret Bright, Report of the Visit of the Delegation from U.S.S.R. Ministry of Healtix to the Demographic Training and Research Centre, Chembur, Bombay, $215 t$ Apris, 1958 (1958).

${ }^{10}$ See LORIMER, op. cit. supra note 13 , at $128-29$.

${ }^{17}$ LORDMER, Op. cit. supra note 13, at 134; TSENTRAL'NOYE STATISTICHESKOYE UPRAVLENIYE PRI SOVETE

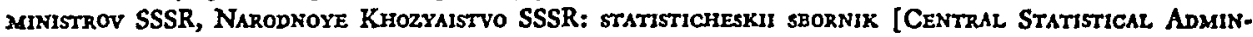
istration of the Council of Ministers of the U.S.S.R., THE NATIONAz Econonit of the U.S.S.R.: A Statisticat Coscpilation] 243 (I956). 
additional child, there are stipends provided in the form of both a lump-sum payment and a monthly allowance. Lump-sum payments vary from 200 rubles upon the birth of the third child to 2500 rubles upon the birth of the tenth and each additional child. Monthly allowances range from forty rubles for four children to a maximum of 150 rubles for ten or more children. ${ }^{48}$

These grants must be seen against an average take-home pay of about 600 rubles per month for the period 1948 -r $95^{2}$, and a possibly higher figure for the period after 1952 . Thus, while it is doubtful that except in a minority of cases the provision of these grants will act as a positive financial incentive to having large families, nonetheless the financial deterrent to such families may be eased considerably, particularly for the low income families, who must spend a substantial portion of their budget on food. 49

Medals for large families, culminating in the "Order of Mother Heroine" (Gold Star), with a scroll from the Presidium of the Supreme Soviet of the Soviet Union, for ten children, are still awarded. This practice has led to an interesting anomaly: $:^{50}$

For some time Soviet population experts have been wondering why Azerbaijan, with only 3,000,000 people has I95 "Mothers Heroine," or as many as the Ukraine with 40,000,000 people. Last week Moscow's Literary Gazette. gave the answer. Azerbaijan is Moslem, and the Moslem faith permits polygamy. Although Soviet law says a man can have only one wife at a time, some Azerbaijani secretly marry extra wives. In order to legitimatize the offspring of their extra wives the fathers have been registering them as the children of their legal wives. Moscow's dilemma is how to cut off the costly subsidies without declaring thousands of children illegitimate.

Although family-allowance schemes appear to be aimed at increasing birth rates, taxes on bachelors and other single and childless citizens were considerably reduced for low-paid workers in March I957, with further exemption in December I957 of people with one and two children and single women without children. ${ }^{51}$ It may well be that these taxes, somtimes cited as pronatalist in intent, are more appropriately to be regarded as revenue-producing.

Similarly, the motivations behind the family allowances may be manifold. They may include the desire for more children; the desire for a larger population, a more rapidly growing population; and the humanitarian wish to assist families on a graduated basis according to the number of their children. Also, it is probable that these measures were partially designed to relieve pressures for wage increases. ${ }^{\mathbf{5 2}}$ The wage and price structures were such as greatly to encourage employment of women. The presence of several children in a family, therefore, undoubtedly caused

${ }^{18}$ Decree of the Presidium of the U.S.S.R. Supreme Soviet, July 8, 1944, as amended, Nov. 25, 1947, Izvestiya, Nov. 26, 1947. See Ministry of Healri, op. cit. supra note 24, at 313-14, 323-24.

40 Field, Social Services for the Family in the Soviet Union, I8 MaRRIAGe AND Famiry Living 244, $245-46$ (1955).

${ }^{\circ}$ N.Y. Times, Feb. 2, $x 958$.

t' See G. Mar'yakhin \& D. Burmistrov, Nalogi s Naselentya y SSSR [Taxing of the Population IN THE U.S.S.R.] 96 (I957); Vedomosti verkhovnogo soveta SSSR, No. 28, 1957, p. 787.

${ }^{62}$ Huyck, Coexistence of Pro-Natalist and Anti-Natalist Policies in the Soviet Bloc, 1959, p. 27 (unpublished manuscript in University of Colorado Library). 
some economic hardship and contributed toward the pressure for wage increases, which family allowances partially relieved. Thus, while family-allowance schemes may be pronatalist in effect, they may, in fact, be dictated by economic considerations only remotely connected with population policy.

Perhaps it is impossible to disentangle the effects of specific measures that pertain to population. The social revolution that has occurred within the Soviet Union, with or without the aid of specific measures relating to population, has led to a marked decline in the birth rate. This crude birth rate was approximately: $:^{53}$

43 in 1926

30 in 1935

$3^{8}$ in $193^{8}$

$3 \mathrm{r}$ in $\mathrm{x} 94^{0}$

27 in $195^{\circ}$

25 in $195^{8}$

The latter figures may be somewhat below normal because of the deficit of males in the reproductive ages-possibly twenty to thirty per cent below normal ${ }^{54}$-but the changes in the rate remind us of similar changes in the western capitalist world.

II

\section{EASTERN EUROPE}

Communist countries in eastern and southern Europe include Albania, Bulgaria, Czechoslovakia, Eastern Germany, Hungary, Poland, Rumania, and Yugoslavia. Their combined population approximates II5,000,000. These countries have only recently come under the domain of the communists. Prior to World War II, in 1938, each of these countries had birth rates below twenty-five, except for Rumania (thirty) and Albania (forty). Czechoslovakia, East Germany, and Hungary reported rates below twenty. Twenty years later, Albania and Poland had birth rates above twenty-five (thirty-nine and twenty-six, respectively). There had been a drop in the rate in Rumania from thirty to twenty-two. Rates in the remaining countries -Bulgaria, Czechoslovakia, East Germany, and Hungary-were sixteen to eighteen. ${ }^{\text {"5 }}$

Considering the fact that most of these countries have had relatively low birth rates for two or more decades, one might expect them to favor a pronatalist policy. Most of these countries do, in fact, have a system of family allowances, as do the noncommunist countries of western Europe. This pronatalist policy is, in part, counterbalanced, however, by the availability of information about and supplies of contraceptives and by laws that permit abortions at the will of the pregnant woman.

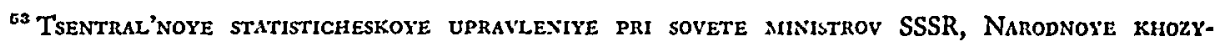
aistvo SSSR v I958 godv [Central Statistical Administration of the Council of Ministers of thie U.S.S.R., NAtional Economy OF THE USSR in I958] 3 I (1959).

${ }^{5}$ Myers, Analysis of Mortality and Fertility Data of the Soviet Union, 74 Pub. Health ReP. 975 (r959).

${ }^{6}$ U.N. Dep't of Economic and Social Affairs, Demographic Yearbook 9, 28 (U.N. Pub. Sales No. 1954.XVII.5); id. tables 9, 25 (U.N. Pub. Sales No. 1959.XIII.r).
} 
Fertility control is widely practiced in most of these countries. Thus, taxes on childless couples have been revoked in some instances, and abortions are permitted for a wide variety of reasons, including economic ones, in Bulgaria, Czechoslovakia, Hungary, Poland, Rumania, and Yugoslavia. ${ }^{50}$ Moreover, abortion is widely accepted, possibly in large part because of ineffective dissemination of information about and supplies of birth-control devices. The extent of abortions in these countries may be judged from the ratio of abortions to births. Available figures indicate that there are about twenty-five abortions per roo births in Poland, thirty-seven in Czechoslovakia, forty-two in Slovenia (figures for all of Yugoslavia have not come to the writer's attention), and slightly more than 100 in Hungary..$^{57}$ Thus, it is seen that whatever the intent of the abortion laws, abortions are being used effectively to reduce the birth rates in a number of communist countries.

In East Germany and Albania, abortion has not been legalized. In the former, heavy war losses during World War II and large-scale emigration since the war undoubtedly have strengthened pronatalist feelings. In the latter, the predominantly rural Moslem population presumably has not undergone sufficient social change to make fertility control a felt need, without reference to the method employed.

Abortions were legalized in the eastern European countries only after the action of the Soviet Union in r955. This suggests that the Soviet Union tends to set the pattern for its satellites. Recently, however, there has been increasing discussion of the retarding effect of rapid population growth on economic development in several eastern European countries, notably Poland, Hungary, and Czechoslovakia. Such discussion is not found in the Soviet Union. There is no evidence of a single uniform "communist population policy"-there is only unanimity in attacking Malthusians, the neo-Malthusians, the bourgeois, and the capitalists.

III

\section{Mannland China}

Relatively little information is available about the size, distribution, and composition of Mainland China's population. In part, this is due to the long history of inadequate statistics for that country; in part, to its lack of communication with other parts of the world; and in part, to a tendency to treat such matters as secret. The Chinese reacted with great pride to the announcement that their population was almost 583,000,000 in mid-r953. In 1960, the total population of Mainland China

${ }^{60}$ Bulgaria: Izvestiya, Feb. Io, 1956 and April 27, 1956; Czechoslovakia: Rude Pravo, Dec. I9, 1957, as reported in Legalized Abortions, East Europe, Feb. 1958, p. 51; Hungary: Decree 1,047-I956 (VI-3) Mt.-h; Poland: Dziennik Ustaw Polskiej Rzeczypospolitaj Ludwej, May 8, 1956, p. 7r; Rumania: Decree No. 463 , Sept. 30, I957; Yugloslavia: Executive Order, June II, 1952.

${ }^{\circ 7}$ Poland: Lesinsky, Abortions in Poland, a paper presented at the International Conference on Abortion Problems and Abortion Control, Rostock Warnemunde, East Germany, May 5-7, I960; Czechoslovakia: Republikx Ceskoslovenske, Statni Urad Statistiky, in Demograficka Prirucra 50 (1959): Slovenia: Report by Professor Franc Novac, Professor of Gynecology, University of Ljubijana, Yugoloslavia, to Dr. Christopher Tietze, Director of Research, National Committee on Maternal Health, New York, N.Y.; Hungary: I Kozponti Statisztikai Hivatai, Demographia 226-48. 
probably is in excess of $650,000,000$; one source gives an estimate of $723,000,000 .^{58}$ One cannot evaluate the accuracy of such figures due to lack of information. But Mainland China's population is huge and growing rapidly.

The communist government has been in power for only a few years. Hence, it would not have been unexpected during this short history had population problems as such not received much attention. It was, therefore, with great surprise that the western world first heard the news of a birth-control program in Mainland China in 1955 and 1956 . Chinese values of reverence for family life and many sons, and the communist thesis that overpopulation was a capitalist, not a socialist, sickness seemed inconsistent with this new program.

The writer has described the birth-control program of Mainland China in considerable detail in a recent paper; ${ }^{59}$ consequently, only the broad outlines of their changing views will be presented here. Late in 1954, several Mainland Chinese writers stressed difficulties associated with rapidly growing populations-e.g., need for additional school facilities. Liu Shao-chi referred to the desirability of family limitation, stating: ${ }^{60}$

Lenin wote in his treatise on "The Working Class and the New Malthusian Theory": "Publicity of medical knowledge and protection of the basic citizenship rights of men and women in a democracy are wholly different from the new Malthusian theory of society."

Many other statements regarding the need for birth control were also made during 1955, 1956, and $1957^{61}$ Most of the authors of these were careful to safeguard their standing within the Party by attacking Malthus, after which they emphasized the desirability of birth control to regulate the spacing of birth, to protect the health of mothers and children, etc. John Aird has commented as follows: ${ }^{\mathbf{2}}$

From this time (late 1954 ) onward, some press attention was given to the subject, but efforts to promote the idea of birth control were evidently sporadic. Even after Chou En-lai endorsed birth control at the Eighth National Congress of the CCP in September 1956, it was noted that public health people were hesitant about taking positive action.

In March 1957 a People's Daily editorial criticized them for failure to meet "this urgent and reasonable demand of the broad masses" and issued a call to "exercise appropriate birth control." Immediately health officials from Minister Li Teh-chuan downward began to make speeches urging the use of birth control and rationalizing the government's case for it on non-Malthusian grounds. An exhibition was opened in Peking. Prices were reduced on contraceptives and the supply of devices increased. A national committee was set up to guide birth control research.

Obviously, there was a change of atmosphere within Mainland China, although there was not necessarily a uniform acceptance of the idea of birth control. For

${ }^{58}$ Aird, The Present and Prospective Poptlation of Mainland Chita, in Mrlbank Memonual Fund, Population Trends in Eastern Europe, the USSR and Mainland China 93 (1960).

${ }^{10}$ Mauldin, supra note 22.

${ }^{60}$ Yang Sze-ying, On the Malthusian Theory of Population, Hsuch Hsi, Oct. 2, 1955, as translated in Extracts from China Mainland Magazines, No. 16, Nov. 28, 1955, pp. 7, 11 .

${ }^{61}$ See Taeuber, Population Policies in Communist China, 22 Population Index 261 (1956).

${ }^{62}$ Letter from John Aird, U.S. Bureau of the Census, Washington, D.C., to the writer, Nov. I3, 1958. 
example, Ma Yin-chu, ${ }^{63}$ the noted economist and President of Peking University, an ardent advocate of the "new principle of population," delivered a speech advocating birth control on July 4, I957, in which he said that he had planned to deliver the speech in I955, but his colleagues either refused to talk with him or disagreed with him. Ma's paper discussed at great length the need for family planning, stressing difficulties of rapid mechanization and automatization, of capital accumulation, of improving technical equipment for workers, of rapid industrialization, of promoting scientific study - all these difficulties being mentioned in relation to rapid population growth. He even said: "One of the reasons for the Polish and Hungarian incidents is precisely because the governments paid attention only to industrialization and not the needs of the people, changing the people's zeal for industrialization into disappointment in life, and thus causing trouble."64

Many writers throughout I957 supported the idea of birth control, usually invoking Lenin or Engels to support their views. For example: ${ }^{65}$

But Engels predicted: "If there is a time when a Communist Society feels obliged to adjust the growth of population, as in the case of adjusting material production before, only such a society can without difficulty realize it." (Engels' letter to Kautsky, published in "Study and Translation Series" Issue No. 3, I958). Marxists, therefore, do not object to birth control.

Various birth-control activities seem to have been undertaken in the period from I954 to early 1956, however inadequate they may have been. It was reported that contraceptive supplies were on sale at the stores of the government-managed China Medical Company. Educational activities were reported as having begun-the party groups and the cooperative organizations being the channels of communication.

But how effective these various measures were is open to question. Shao $\mathrm{Li}-\mathrm{Tzu}$, following two inspection trips into the countryside in 1956 , stated: ${ }^{86}$

I had conversations with women cadres and women cooperative members. . . . When I asked them if they were aware of the birth control methods, practically all of them replied that they did not know a thing about it. Some said that they had heard of a certain medicine procurable in the city for that purpose but they did not know any details about it. ...

\section{And Chen Ta said at a meeting on May 27, $19577^{.07}$}

Promotion of birth control: This is of great consequence to the nation and to the people. I have great respect for the Communist Party for publicizing this problem. There is no

${ }^{03} \mathrm{Ma}$ Yin-chu, A New Principle of Population, Jen Min Jih Pao (Peking), July 5, I957, as translated in Union Research Service, vol. 86 , no. 6, July I9, I957, p. 84 .

ollbid.

es Wang Tso \& Tai Yuari-chen, Criticism and Appraisal of the "New Theory of Population," Ching Chi Yen Chiu, Feb. 17, r958, as translated in Extracts from China Mainland Magazines, No. I28, May I2, I958, pp. 5,7 .

${ }^{60}$ Kung Jen Jih Pao, June 28, 1956.

or Symposium called by the Director of the State Statistical Bureau on May 27, 1957 to help in the rectification of the State Statistical Bureau, T'ung Chi Kung Tso, Nov. 12, 1957, p. I. 
relationship between birth control and Malthusianism. In our country the vital question lies in implementation. The faster it is done, the better. It should be started on a small scale and be extended, but so far nothing has been done; especially in extending the program from cities to rural areas.

There were signs in the fall of 1957 , however, that the political winds had returned to their earlier direction. By 1958 , it was clear that the leaders either had abandoned the newly acclaimed position of the desirability of limiting family size or else had temporarily shelved publicity advocating such a position.

An article in the Peking Jen Min Jih Pao on October 9, x957, argued the need for birth control in order to prevent a decline in living standards. On October 14, five days later, another article appeared bitterly attacking "rightists" for taking advantage of the controversy over population birth-control problems to launch assaults on the Party and on socialism. The attacks were especially directed against $\mathrm{Ma}$ Yin-chu and Fei Hsiao-t'ung, President of the National Institute for Minorities, both ardent advocates of birth control. Another article in the same paper on February $\mathrm{I}$, I958, attacked both the "leftist" and the "rightist" views on population. It characterized the former as holding the classical communist doctrine that a huge human population raises no problem at all, and the latter as maintaining that a large population is "absolutely a bad thing." The paper stated that the Party opposed both views but was not blind to two difficulties of a large population. One difficulty arose from the limitations of China's economy, and the other from the high rate at which the population was increasing. 68

Criticisms of those who had advocated birth control because of economic reasons appeared with increased frequency in 1958 . In February 1958 , Chu Pao-yi ${ }^{60}$ attacked Wu Ching-chao's article, "New Views on the Problem of Chinese Populations." Ma Yin-chu was attacked in the papers on April 19, 1958, April 26, and again on June $25 .{ }^{70}$ These attacks were made by students of the University, among others. Other spokesmen emphasized that "it is now entirely safe for us to say that the Chinese people can determine the increase in their grain output according to their needs. ... . If we have to, we can produce as much food as we desire."71 The new production figures led Mainland Chinese writers to state that the "theory of the backwardness of agriculture" in China is invalid. The new figures "smash to pieces the reactionary theory that "the increase of grain cannot catch up with the needs of in-

${ }^{88}$ See Birth Control Propaganda, East Europe, July 1959, p. 32, for a discussion of the articles of Oct. 9, 1957 and Feb. $x, 1958$. The writer is indebted to Leo Orleans for the reference and discussion of the article of Oct. I4, 1957 .

${ }^{\circ}$ Chu Pao-yi, Refutation of Wu Ching-chao's Slanderous Remarks Against the Chinese People on the Population Issue, Tsai Ching Yen Chiu, Feb. 15, 1958, as translated in Extracts from China Mainland Magazines, No. 128, May 12, 1958, p. I7.

${ }^{10}$ Kuang Ming Jih Pao (Peking), April 19, April 26, and June 25, 1958.

${ }^{11}$ China Can Produce All the Grain It Wants, Jen Min Jih Pao (Peking), July 23, 1958, as translated in Survey of China Mainland Press, No. 1823, July 31, 1958, p. 15; also Shie P'ing, The Preposterous Version of China's Backwardness in Agriculttre 1s Bankrupt, Hsueh Hsi, Aug. 3, 1958, as translated in Extracts from China Mainland Magazines, No. 147, Nov. 3, 1958, p. 1 I. 
creased population' .... Above all, Malthus has finally been dealt a final blow."72 These examples could be multiplied, ad nauseam. In general, however, there has been but little in the Mainland Chinese press relating to population policy since September 1958 .

Dr. Ma Yin-chu refused to modify his views, and late in I959, he reiterated that Mainland China's population growth should be reduced. ${ }^{73}$ But such sentiments seem out of keeping with the majority of press comments, out of keeping with the remarks to most visitors to Mainland China who ask about current policies. It appears that birth control is still permitted, but is no longer pushed as an end desired by the State. We have no information about the frequency of abortions, sterilizations, or the availability and use of contraceptives.

Nor do we know what led to the shift in policy. John Aird, in an unpublished manuscript, makes a convincing case of the shifts in policy being tied to food supply: $:^{74}$

By the fall and winter of 1956 , with food anxieties rising to a new climax, the central leadership evidently decided that they must attain immediate control of population growth. In the hope of enlisting greater cooperation from the population for this and other ventures, the hundred flowers campaign was unveiled. This gambit apparently backfired, and the leadership cracked down on the intellectuals who had dared to bloom with weed-like vigor.

The abandonment of the birth control campaign in June 1958 was clearly due to the fact that high Party and government officials were confident of the reports of a bumper harvest in the making which were being received in late spring.

Leo Orleans suggests that the favorable situation in $195^{8}$ was not sufficient to cause a reversal in policy. ${ }^{75} \mathrm{He}$ is aware of the current communist line stressing the shortage of labor throughout the country. In spite of these signs, it is his feeling that the so-called reversal is both temporary and partial. Birth control is still permitted, is has just been pointed out. Orleans thinks that the primary factor in the new line adopted by the Chinese is their recognition of the difficulties of implementing a fertility-reduction program-difficulties of supplies, of methods, of changing the attitudes of the peasants. The increased production will give them a respite in which they can approach the problem of population more realistically. The current view, and the one that is likely to continue, is well summarized in the following statement: ${ }^{76}$

${ }^{73}$ Chang Kuei-shun, Refute the Bourgeois "Law of Diminishing Returns of Land," Weh Hui Pao (Shanghai), Aug. 14, 1958, as translated in Survey of China Mainland Press, No. 1845, Sept. 3, 1958, p. I7.

${ }^{73} \mathrm{Ma}$ Yin-chu, My Philosophical Thinking and Economic Theory, Hsin Chien-she, Nov. 7, 1959, as translated in Extracts from China Mainland Magazines, No. I95, Jan. I, r960, pp. I, 39-45. See N.Y. Times, Jan. 16, 1960, p. 8, cols. I-2. Dr. Ma Yin-chu has been dismissed from his post as President of Peking University, as of April 17, 1960. Indian Express (Bombay), April 18, 1960.

7t Those interested may obtain more specific information' by writing to John Aird, Foreign Manpower Research Office, U.S. Bureau of the Census, Washington 25, D.C.

${ }^{70}$ In an unpublished paper, Communist China's Birth Control Policies: Reversal or Postponement. Those interested may obtain more specific information by writing to Leo Orleans, Library of Congress, Washington 25, D.C.

${ }^{70}$ Su Chung, Facts About China's Population, Peking Rev. July I, 1959, pp. 9, 10. 
China's aim is to adjust her population growth in such a way as to benefit the whole socialist planned economy and the welfare of the people. With culture and scientific knowledge spreading on a mass scale, the prospect is that planned birth will be progressively understood and accepted by the people.

- Others argue that the shift in policy is a reflection of traditional theorists again gaining the upper hand within the Party circles. Whatever the cause for the shift in policy, it is evident that communist actions relating to population are not tied to any specific doctrine-and certainly not to a nonexistent Marxist doctrine. Marx was highly critical of Malthus, of the concept of absolute overpopulation, of the bourgeois, etc. But in the field of population, what was he "for"? As was stated by a Chinese writer in May 1959: ${ }^{77}$

$\ldots$ in denouncing the reactionary Malthusian theory, Marxists did not in any way exclude the necessity of the planned limitation of population growth in the future development of society.

Communist doctrine is, indeed, quite flexible in this area.

\section{SUMMARY}

Throughout the communist world-the Soviet Union, the so-called people's democracies of eastern Europe, and Mainland China-many changes are taking place. The death rates have fallen rapidly; and in those countries where urbanization and industrialization have moved ahead rapidly, there have been declines in the birth rate-in fact, birth rates had declined in eastern European countries prior to the establishment of communist control. The revolutions that brought into power the new regimes have been far-reaching in undermining-in virtually eliminating-the influence of many of the old institutions. The social order is, indeed, changing. There is a premium on education, on acquiring new skills, on vertical mobility. Industrialization is highly prized. Women have been emancipated, or are in process of being emancipated. There is an insistence on revolution, which is conducive to questioning the old ways, toward accepting new ways. The little evidence we have to date, primarily from the Soviet Union, is that the process of change, of education, of emancipation of women, of industrialization, urbanization, modernization, leads to values among the individuals that bring about a reduction in the birth rate.

It is clear that in most of the communist countries, fertility control is widely practiced. These countries have adopted family-allowance programs and honor awards for mothers of many children. These are pronatalist policies. There is reason to believe, however, that the primary motivations behind the family-allowance programs have been otherwise. Antinatalist measures have been enacted, including legalization of abortion, spread of supplies of and information on contraceptives, maximizing the female labor force, etc. There has been increasing attention paid to

\footnotetext{
${ }^{n 7}$ T'ien Feng-tiao, China's Planned Births and Population lncrease, Jen Min Pao Chien (Pcking), May I, 1959.
} 
the relationship between rapid population growth and the provisions of adequate housing, schooling, rapid mechanization and automation, and capital accumulation. Above all, there is stress on improving health of mothers and children, of a woman giving birth only when she wants a child and is able to rear one.

Population needs and population policy vary among the various communist countries. Pronatalist and antinatalist policies exist side by side. The larger processes of social and economic change are bringing about the reduction in the birth rates. This trend toward declining birth rates has not been combatted vigorously by the communist countries; at least, it has not been combatted any more vigorously there than in a number of western countries. In fact, there is increasing evidence of a rational consideration of the relationship between rates of population growth and economic development in many of the communist countries. 